Original scientific paper

Received 30.12.2017.

Approved 14.03.2018.

\title{
THE RELATIONSHIP BETWEEN INNOVATION AND SUCCESS: THE CASE STUDY OF YOOX S.P.A.
}

In the current competitive context, the exponential growth rates of progress and technology lead to a rapid obsolescence of ideas and products, leading to the reduction of the relative life cycles and profit margins. In this context, the intrinsic characteristics of the product are no longer enough, and the ability to interpret and advance the real needs of the market becomes fundamental. The primary purpose of this paper is to highlight the strategic importance of innovation as the main tool with which the company can adapt to change or be its engine.

The case study proposed here explores the development's path of an Italian innovation-oriented company: Yoox S.p.a.. The analysis, based on sturdy theoretical foundations, retraces the path growth of the company, highlighting its extraordinary propensity for innovation as its main critical success factor.

While analyzing this case study, the role played by companies in generating discontinuities that break and redefine the equilibrium in the competitive context is also highlighted. Focusing on this perspective, the original strategic positioning model and the business model that allowed Yoox to reconfigure the traditional market boundaries and redesign the consumers purchasing process are described.

Keywords: strategy, innovation, technology, development

e-Campus University, Novedrate, Italy

dapietro1988@gmail.com 


\section{Introduction}

Entrepreneurship is the main driver for economic growth because it is an irreplaceable source of innovation ${ }^{1}$. The OECD, the Organization for Economic Cooperation and Development, defines entrepreneurship as the ability to innovate, risk and seek new ways of development. The growing importance of innovation in the competition for survival is also highlighted by Bertelé and Mari$\mathrm{otti}^{2}$ (1991) who speak of innovation as a mandatory choice in the contemporary economy.

We often talk about the "innovation process" to emphasize the dynamic dimension of the phenomenon. In fact, it has been observed ${ }^{3}$ that only continuous innovation represents the new, the true strategic factor of entrepreneurial success. In the current economy of complexity and globalization, more and more a successful company is that which is born innovating, grows innovating and establishes itself and continues over time, continuing to innovate. It has also been observed ${ }^{4}$ that innovation is a discontinuity that feeds on continuity: the new is necessarily the result of the past, must be produced by history even if it then constitutes a break. To underline the constancy of the innovative effort over time there is also the thought of Ciappei and Poggi ${ }^{5}$ (1997) who spoke of a real "innovation routine" that must be promoted by the company management, to understand the fact that innovation and attention to the future must be placed at the base of everyday business life.

The main purpose of this paper is to highlight that the road of innovation is that which more than others allows a company not only to survive in competitive "hostile" contexts but also to succeed successfully where it is possible to play a role proactive in defining new business.

It is in this context that we consider the case study of the company Yoox S.p.a., which - as will be shown - has innovated the fashion world, breaking the relevant market pre-existing balances and drawing new competitive dynamics.

The main innovation brought to the fashion world by Yoox lies in the application of information technology in a context different from those where it usually found its application. It was something unimaginable, if one considers

Consolini, M., Di Saverio M., Loasses C. \& Richini P. (2013): Indicazioni per la programmazione e la realizzazione di iniziative per l'educazione all'imprenditorialità, ISFOL, Roma.

2 Bertelé, U., Mariotti, S. (1991): Impresa e competizione dinamica. Complessità economica, efficienza d'impresa e cambiamento industriale, Etas, Milano.

3 Dioguardi, G. (2000): L'impresa flessibile: una risposta alla competizione globale, in Bertelè U., Mariotti S., Impresa e competizione dinamica. Complessità economica, efficienza d'impresa e cambiamento industriale, Etas, Milano.

4 Vicari, S. (1998): La creatività dell'impresa. Tra caso e necessità, Etas, Milano.

5 Ciappei, C., Poggi, A. (1997): Apprendimento e agire strategico d'impresa. Il governo delle dinamiche conoscitive nella complessità aziendale, Cedam, Padova. 
what the clothing market was before the debut of this kind of 'virtual outlet', which later became a direct sales channel. In fact, as claimed by Viale (2008), in a global competitive scenario in which technology and demand change rapidly and unpredictably, the success of a company can no longer be based on the mere control of resources or competences that provide a temporary competitive advantage; it derives rather from the ability to constantly generate and continuously renew a flow of resources and skills that competitors find difficult to imitate. Without this, the company will see its competitive edge gradually erode. As a matter of fact, that of Yoox is not the story of a company that has been successful because it has innovated, but that of a company that has established itself because it has continued to innovate ${ }^{6}$. In the first delicate phase of the launch of the new 'product', the start-up kept a low profile, limiting itself to offering online out-of-series high-fashion items at very discounted prices. At the same time, it has continued to innovate, expanding combinations and geographical areas of its offer, to the point of establishing itself as a real brand.

\section{Literature review}

The intensification of international competition, the changing and globalized needs of demand, as well as the accentuated technological evolution, have increasingly moved the focus of competition towards innovation?

The first author to develop a true theory of innovation is Schumpeter.

According to Schumpeter ${ }^{8}$, the entrepreneur is the one who disturbs the equilibrium of a market by developing innovative production combinations, which in turn generate a sort of temporary monopoly position for those who introduced them (the first mover advantage), which is a source of extra profit for the company. The position thus reached is not permanent, but is progressively eroded by the imitating action of new economic factors. This leads to the re-establishing of the general equilibrium, at least until another entrepreneur disturbs it again with another invention. And the process begins again, in a succession of renewals that form the technological and socio-economic progress.

6 As the failures of many small innovative companies show, «the competences of development, organization, distribution, marketing, communication and financial are what makes the difference and allow a good idea to become a successful product» (Viale, 2008).

Viale, R., Etzkowitz, H. (2008): The Capitalization of Knowledge: A Triple Helix of University-Industry-Government, Edward Elgar, Cheltenham, UK.

7 Stampacchia, P., Bifulco, F. (2005): La gestione dei percorsi di innovazione, Giappichelli, Torino.

8 Schumpeter, J. (1934): Theorie der Virtschaftlichen Entwicklung, Duncken \& Humboldt, Berlino. 
Schumpeter's intuitions have given rise to another important area of study - Entrepreneurship ${ }^{9}$, which refers to an ability that combines three orientations:

- the ability to identify profitable market opportunities, before other players;

- $\quad$ the proneness to take risks;

- the identification and mobilization of an adequate pool of resources to achieve a certain goal $^{10}$.

On the other hand, according to Casson ${ }^{11}$, entrepreneurship studies represent a real business theory, with principles and assumptions that are very different from other models. Certainly, innovation has to do with creativity, which can be defined as the combination of pre-existing elements through new connections. The output is an idea that, while valorizing existing knowledge, finds an answer to a problem using new and unusual schemes and mechanisms which have never been used before.

Thus, innovation can consist either in doing something new brilliantly or in doing more effectively or efficiently something that has already been done in the past. Both roads are possible for a company that wants to be the successful. Indeed, the condition of excellence has been the object of some empirical studies at least since the eighties ${ }^{12}$. The two American authors studied some big world enterprises, highlighting eight attributes of excellence. Simon and Zatta ${ }^{13}$ considered the medium-sized enterprises of success, the so-called "hidden champions", identifying the 9 lessons at the base of their competitiveness.

Preti and Puricelli ${ }^{14}$ have instead focused their attention on the small successful companies, setting up a "decalogue of the strong enterprise".

The following table summarizes, in terms of comparison, the characteristics of the winning company identified by the authors.

$9 \quad$ Kirzner, I. (1973): Competition and Entrepreneurship, London University of Chicago Press, Chicago.

Birkinshaw, J. (1997): Entrepreneurship in Multinational Corporations: The Characteristics of Subsidiary Initiatives, Strategic Management Journal, vol. 18.

Zucchella, A., Scabini, P. (2007): International Entrepreneurship, Palgrave, London.

10 Birkinshaw, J. (1997).

11 Casson, M. (2005): Entrepreneurship and the theory of the firm, Journal of Economic Behavior \& Organization, 58(2), 327-348.

12 Peters, T. (1982): Waterman R., In Search of Excellence, Harper \& Row, New York.

13 Simon, H., Zatta, D. (2007): Campioni nascosti. Come le piccole e medie imprese hanno conquistato il mondo, Il Sole 24 Ore, Milano.

14 Preti, P., Puricelli, M. (2007): L’impresa forte. Un manifesto per le piccole imprese, Egea, Milano. 
Table 1: The main definitions of innovation

\begin{tabular}{|l|l|l|}
\hline Author & Definition of innovation & Tags \\
\hline Schumpeter & $\begin{array}{l}\text { uncontrollable phenomenon that constantly } \\
\text { disturbs the endogenous equilibrium of the } \\
\text { economy, a destructive force that constantly cre- } \\
\text { ates progress thanks to the action of innovative } \\
\text { entrepreneurs }\end{array}$ & $\begin{array}{l}\text { discontinuity, } \\
\text { process, entre- } \\
\text { preneurship }\end{array}$ \\
\hline Thompson $^{16}$ & $\begin{array}{l}\text { acceptance and implementation of new ideas, } \\
\text { processes, products or services }\end{array}$ & $\begin{array}{l}\text { novelty, imple- } \\
\text { mentation, } \\
\text { process, success, } \\
\text { different types }\end{array}$ \\
\hline Schumpeter $^{17}$ & introduction of new production combinations & novelty, product \\
\hline Freeman & $\begin{array}{l}\text { marketing process of an invention at product, } \\
\text { process or system level }\end{array}$ & $\begin{array}{l}\text { process, market, } \\
\text { novelty, differ- } \\
\text { ent types }\end{array}$ \\
\hline Porter $^{19}$ & $\begin{array}{l}\text { introduction of a new technology or a new way of } \\
\text { doing things }\end{array}$ & $\begin{array}{l}\text { implementation, } \\
\text { novelty }\end{array}$ \\
\hline Henry, Walker $^{20}$ & $\begin{array}{l}\text { set of activities that allow a new product or pro- } \\
\text { cess to enter the market or become common use }\end{array}$ & $\begin{array}{l}\text { novelty, process, } \\
\text { market }\end{array}$ \\
\hline Rogers $^{21}$ & $\begin{array}{l}\text { application of new ideas to a product, process or } \\
\text { any other aspect of the business activity }\end{array}$ & $\begin{array}{l}\text { ideas, process, } \\
\text { different types }\end{array}$ \\
\hline Drucker $^{22}$ & $\begin{array}{l}\text { specific entrepreneurship's function, the entre- } \\
\text { preneur creates values through new or pre-exist- } \\
\text { ing resources }\end{array}$ & $\begin{array}{l}\text { function, value, } \\
\text { resources }\end{array}$ \\
\hline
\end{tabular}

Source: Author's elaborations.

15 Schumpeter, J. (1934).

16 Thompson, A. V. (1965): Bureaucracy and innovation, Administrative Science Quarterly, vol. 10, n. 1, 1-20.

17 Schumpeter, J. (1971): Teoria dello sviluppo economico, Sansoni Editore, 76.

18 Freeman, C. (1982): The Economics of Industrial Innovation, MIT Press, Boston.

19 Porter, M. (1990): Competitive Advantage of Nations, Harvard Business Review, vol. 68, n. 2, 73-93.

$20 \quad$ Henry, J., Walker, D. (1991): Managing Innovation, Sage, London.

21 Rogers, M. (1998): The definition and measurement of innovation, Melbourne Institute of Applied Economics and Social Research, University of Melbourne, Melbourne Institute Working Paper.

22 Drucker, P.F. (2002): The discipline of innovation, Harvard Business Review, vol. 80, n. 8, 95-103. 
Table 2: The characters of the winning company

\begin{tabular}{|l|l|l|}
\hline $\begin{array}{l}\text { Peters-Waterman, 1982 } \\
\text { The 8 characters of excel- } \\
\text { lence }\end{array}$ & $\begin{array}{l}\text { Simon-Zatta, 2007 } \\
\text { The 9 lessons of the hidden } \\
\text { champions }\end{array}$ & $\begin{array}{l}\text { Preti, 2007 } \\
\text { The Decalogue of the strong } \\
\text { enterprise }\end{array}$ \\
\hline proneness to action & ambitious goals & $\begin{array}{l}\text { target of maximization in } \\
\text { the medium-long term }\end{array}$ \\
\hline proximity to the customer & proximity to the customer & challenging comparisons \\
\hline $\begin{array}{l}\text { autonomy and entrepre- } \\
\text { neurship }\end{array}$ & continuous innovation & innovating \\
\hline key value of the activity & focus on the market & $\begin{array}{l}\text { from cost reduction to } \\
\text { quality and service }\end{array}$ \\
\hline $\begin{array}{l}\text { concentration on the core } \\
\text { business }\end{array}$ & $\begin{array}{l}\text { strong competitive advan- } \\
\text { tages }\end{array}$ & $\begin{array}{l}\text { do what is always done bet- } \\
\text { ter }\end{array}$ \\
\hline elasticity / rigidity checks & global orientation & flexible borders \\
\hline $\begin{array}{l}\text { simple structure, reduced } \\
\text { staff }\end{array}$ & $\begin{array}{l}\text { reliance on one's own } \\
\text { strength }\end{array}$ & manage the size \\
\hline $\begin{array}{l}\text { productivity through } \\
\text { people }\end{array}$ & motivated staff & $\begin{array}{l}\text { make a difference thanks } \\
\text { to organization and human } \\
\text { resources }\end{array}$ \\
\hline & & strong entrepreneurship \\
\hline & strong leadership & rootedness in the territory \\
\hline
\end{tabular}

Source: Reprinted from "Alla ricerca dell'unicità. Il management imprenditoriale tra strategia, organizzazione e leadership”, by D’Amato V., Minelli E., Rebora G. (2009).

From this comparison, we can observe an increasing relevance of the factors linked to the market and to global competition, but not a true paradigm shift. The factors considered essential for the competitiveness of companies seem to evolve around continuity, always focusing on the ability to innovate, on the cultivation of distinctive skills and on the good organization ${ }^{23}$.

23 D’Amato, V., Minelli, E., Rebora, G. (2009): Alla ricerca dell'unicità. Il management imprenditoriale tra strategia, organizzazione e leadership, Franco Angeli, Milano. 


\section{Empirical results: the case study of Yoox}

\subsection{Yoox's history}

Yoox operates in the global sales of apparel and fashion accessories of prestigious brands through an innovative e-commerce platform.

The company, founded in 1999 from an idea by Federico Marchetti, represents the perfect synthesis between his entrepreneurial vision and his passion for fashion and design.

Already in the name 'YOOX', the company expresses the essence of the model it is inspired by. The two consonants $\mathrm{Y}$ and $\mathrm{X}$ represent the female and the male chromosome; the 'zero' between the two letters is the zero of the binary code, the language at the base of the information technology. The company main purpose is to keep innovating the market, as it has been doing since it was started, but this purpose is only achievable if adequately equipped; it is necessary to find traveling companions who are motivated to reach the goal and aware of the obstacles that needs to be overcome. In fact, the ambitions of the young entrepreneur Marchetti were only possible thanks to the support of several financiers (Elserino Piol's Kiwi Investment and the European fund Venture Capital Net Partners), despite the hostility and skepticism of the main incumbents in the sector. When the start-up was founded, the fashion market was characterized by permanent and strong established brands, thus leaving no room for new entrants. Afterwards, the company continued its growth path with the help of several Italian and foreign venture capital funds.

Activity officially began with the opening, in June 2000, of the multimarcayoox.com website, initially active in Italy and in other European countries. In 2002, Yoox Corporation was set up to manage activities in the United States, followed by Yoox Japan in 2004, to control the Japanese market. In view of the success and acquired know-how, in 2006 the Group integrated its offer by designing and launching its first Online Store, to which many others will follow for the main international fashion brands. Furthermore, 2006 marked a strong acceleration in the international development of the Group's business, thanks to the extension of its activities to 25 other countries in the world. In accordance with the continuous innovation, in the first half of 2008, the multi-brand business line was expanded through the launch of a second online store, thecorner.com, whose offer is made through mini shops dedicated to collections of well-established, niche or craft-made apparel brands.

In 2009, Yoox entered 14 more countries, further extending its geographical coverage and bringing its presence to 67 countries; from 3 December 2009, it is listed on the STAR segment of the Italian Stock Exchange.

In confirmation of the important achievements, in 2011, the President of the Italian Republic gave the Leonardo Innovation Award to the company. In 
2015 a world-leading Group was born characterized by enormous expertise and a global platform developed to build stronger partnerships with luxury brands. In October 2015, Yoox completed the merger with The Net-A-Porter Group, creating Yoox Net-A-Porter Group, a global leader in fashion luxury e-commerce. Federico Marchetti became its Chief Executive Officer.

The merger has combined two companies with highly complementary businesses and significant synergistic potential in terms of geographical markets, skills and customers.

Here is a representation of the company's growth through the evolution of its Key Performance Indicators:

Table 3: Key Performance Indicators of Yoox in the period between 2010 and 2014

\begin{tabular}{|c|c|c|c|c|c|}
\hline & 2010 & 2011 & 2012 & 2013 & 2014 \\
\hline $\begin{array}{c}\text { Visitors per month } \\
\text { (millions) }\end{array}$ & 8,6 & 10,4 & 13,0 & 13,2 & 15,2 \\
\hline $\begin{array}{c}\text { Number of orders } \\
\text { (millions) }\end{array}$ & 1,5 & 2,1 & 2,3 & 2,8 & 3,4 \\
\hline $\begin{array}{c}\text { Average Order Value } \\
\text { (euros) }\end{array}$ & 179 & 180 & 206 & 215 & 202 \\
\hline $\begin{array}{c}\text { Number of active } \\
\text { customers }\end{array}$ & 612 & 808 & 947 & 1.081 & 1.252 \\
\hline
\end{tabular}

\subsection{Dynamics of the relevant market and Yoox's strategic positioning}

Yoox managed to penetrate a mature market by inventing a new business environment, where competitors did not yet exist. There is often a strong opposition between entrants, the new companies that renew the market in order to overcome its entry barriers and incumbents, ie those companies that occupy a privileged position in the market and have to decide whether to oppose the changes or to align with them (Henderson and Clark, 1990).

In recent years, the online retail market Yoox operates in the fashion sector ${ }^{24}$, has experienced strong growth. There are many reasons, including the greater selection of products offered online, the search for convenience, the growing perception of security for online purchases, the growing trend in the number of Internet users and those who complete online purchases as well as the emergence of a more and more 'digitally native' new generation.

At the same time, a growing number of fashion, design and luxury companies have approached the Internet world over the years, thus recognizing the strategic nature of this channel as a useful mean to expand visibility and offer on a global level and to establish a more direct relationship with the customers.

$24 \quad$ Defined as the grouping of clothing, footwear, jewelry and watches markets. 
More and more companies improved the shopping experience, invested in online content and alternative channels such as social and mobile commerce, thus supporting the growth of online sales over the long term.

Here are the results achieved on the online retail market from 2010 to 2015 in the various geographical areas.

Table4: Online market trends in the period between 2010 and 2015

\begin{tabular}{|c|c|c|c|c|c|c|}
\hline & 2010 & 2011 & 2012 & 2013 & 2014 & 2015 \\
\hline $\begin{array}{c}\text { Sales Western } \\
\text { Europe }^{25}\end{array}$ & 81 & 97 & 97 & 128 & 161 & 202 \\
\hline Sales in $\mathrm{USA}^{26}$ & 176 & 202 & 231 & 262 & 297 & 338 \\
\hline Sales in Japan ${ }^{27}$ & 4.028 & 4.547 & 5.091 & 5.699 & 6.462 & 8.572 \\
\hline
\end{tabular}

Table5: Fashion sector shares in the period between 2010 and 2015

\begin{tabular}{|l|c|c|c|c|c|c|}
\hline & $\mathbf{2 0 1 0}$ & $\mathbf{2 0 1 1}$ & $\mathbf{2 0 1 2}$ & $\mathbf{2 0 1 3}$ & $\mathbf{2 0 1 4}$ & $\mathbf{2 0 1 5}$ \\
\hline $\begin{array}{l}\text { Western } \\
\text { Europe }\end{array}$ & $18 \%$ & $23 \%$ & $21 \%$ & $25 \%$ & $22 \%$ & $24 \%$ \\
\hline USA & $20 \%$ & $21 \%$ & $21 \%$ & $21 \%$ & $22 \%$ & $18 \%$ \\
\hline Japan & $20 \%$ & $20 \%$ & $21 \%$ & $21 \%$ & $21 \%$ & $22 \%$ \\
\hline
\end{tabular}

Yoox understood all this: from the beginning, it had a clear international vocation. The geographic configuration of the value architecture represents a relevant dimension in order to interpret the innovation processes ${ }^{28}$. In the past, innovation and internationalization were considered strategic alternatives as both are associated with significant risks and investments ${ }^{29}$. Recent studies show that innovation and internationalization can not only be pursued at the same time, but also that, combined with entrepreneurial skills, they are a particularly effective mix for business success ${ }^{30}$. Yoox's cleverness was not so much in being 25 Compound annual growth rate. Values in billions of euros.

26 Based on Forrester Research data - "Online retail forecast, 2010 to 2015 (US), Forrester Research Inc., 18 gennaio 2011". Values in billions of dollars.

27 Based Forrester Research data - "Online retail forecast, 2010 to 2015 (Asia Pacific), Forrester Research Inc., 15 ottobre 2010". Values in Yen.

28 Bursi, T. (2007): I processi di internazionalizzazione delle piccole e medie imprese della provincia di Modena. Il ruolo degli investimenti diretti all'estero, FrancoAngeli, Milano.

29 Ansoff, H. I. (1957): Strategy for Diversification, Harward Business Review, vol. 35, n. 5, 113-124

Zaheer S. (1995): Overcoming the Liability of Foreignness, Academy of management Journal, n. 38, 341-363

30 Zucchella, A., Onetti, A. (2008): Imprenditorialità, internazionalizzazione e innovazione: $i$ business model delle imprese biotech, Carocci, Roma. 
able to market products/services on a global scale, but rather in being able to glimpse and take opportunities directly in the place where these could be generated (Zucchella and Scabini, 2007). In other words, Yoox did not limited itself to replicating in new contexts the successful innovation experienced in the domestic market, thus rejecting a centralized model where the subsidiaries are merely passive transmitters of the strategies established by the head office ${ }^{31}$. In today's complex context, characterized by contemporary phenomena, the real benefits of innovation are obtained when internationalization is managed to feed the processes of innovation, as well as to fully exploit the results ${ }^{32}$. In fact, Yoox has always pursued a balanced growth strategy on a global scale, aiming at international expansion. In its internationalization process it has often acted as first mover, like with China. Asian markets have been a major growth frontier for e-commerce and luxury markets, a circumstance understood and exploited by Yoox. According to Forrester Research, in 2010 China represented the world's largest market for Internet users and according to the World Luxury Association had already surpassed the United States, becoming the second country in the world for consumption of luxury goods, second only to Japan.

Yoox has positioned itself exactly at the point of convergence between these two high growth sectors ${ }^{33}$. According to Forrester Research in October 2010, the online fashion market in China ${ }^{34}$ would have achieved sales of approximately CNY 64 billion (equal to approximately 7 billion Euro), up 57\% compared to 2009. Although it was a relatively small market compared to the others described above, Forrester forecast a significantly higher 2010-2015 CAGR of 22\%. Here are the numbers of the comparison:

Table 6: Sales in the Chinese online fashion market in the period between 2010 and $2015^{35}$

\begin{tabular}{|l|c|c|c|c|c|c|}
\hline & $\mathbf{2 0 1 0}$ & $\mathbf{2 0 1 1}$ & $\mathbf{2 0 1 2}$ & $\mathbf{2 0 1 3}$ & $\mathbf{2 0 1 4}$ & $\mathbf{2 0 1 5}$ \\
\hline Sales realized $^{12}$ & 64 & 87 & 229 & 385 & 560 & 951 \\
\hline
\end{tabular}

\subsection{Business Model and Corporate Responsibility}

Yoox's success is supported by an original strategy based on an equally innovative organizational and governance structure. If generally do not share strategic, organizational and managerial models, on the contrary, in its drive towards

$31 \quad$ Bartlett, C. A., Ghoshal, S. (1992): What is a global manager?, Harward Business Review, vol. 70, 124-132

32 Denicolai, S. (2009): Economia e management dell'innovazione. Governo e intermediazione della conoscenza come leva di competitività, Franco Angeli, Milano.

33 Source: Yoox's balance sheet.

34 Defined as the grouping of clothing, footwear, jewelry and watches markets.

35 Values in Chinese Yuan (CNY). 
innovation, Yoox has generated something unique that has become a winning factor precisely because it is unique, that is, temporarily not reproducible.

Yoox has distinguished itself and continues to stand out for the uniqueness of its business formula, thanks to the following dynamic:

\section{Figure 1}

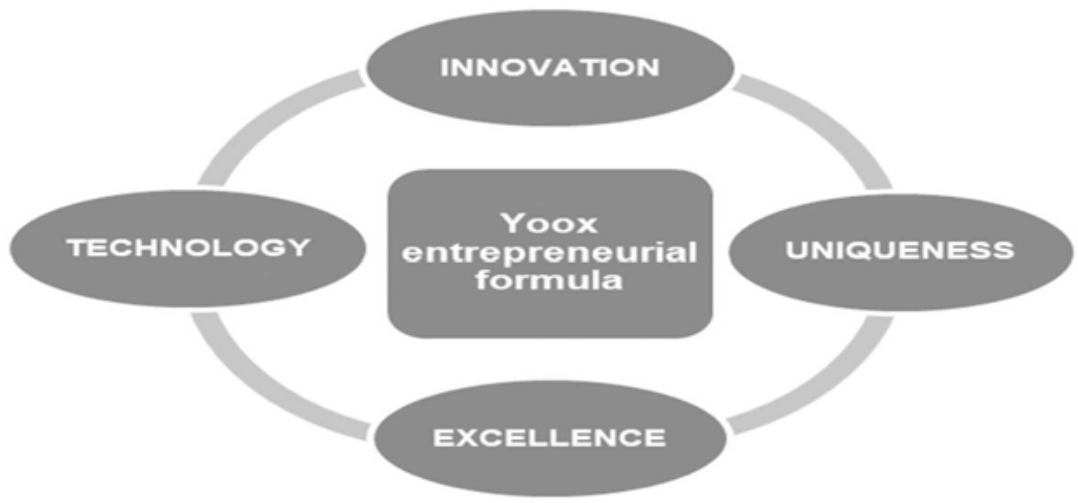

To better understand phenomena like Yoox, it is necessary to take into consideration what gives concreteness to the innovative strategy: the business model, which can itself be a source of innovation. The latter is not based solely on the degree of originality of the value proposition, but also on the model that allows it to be managed (Zucchella and Onetti, 2008). For this reason, the Yoox's innovation lies not only in its strategy, but also in its business model based on the philosophy of the outlet, emphasized by the potential of the Web: the purchase of items out of series and/or of past seasons creates value for customers (low-priced branded products), for suppliers (who can sell the obsolete stock), and of course for the company itself (Denicolai, 2009).

The significant positive cash flows generated over time by operational activities were possible thanks to a single business model on a global scale, characterized by two lines (multi-brand and single-brand) that are based on the same techno-logistics platform and are based on shared skills, thus creating strong synergies and an effective operational leverage at Group level.

\section{Figure 2}

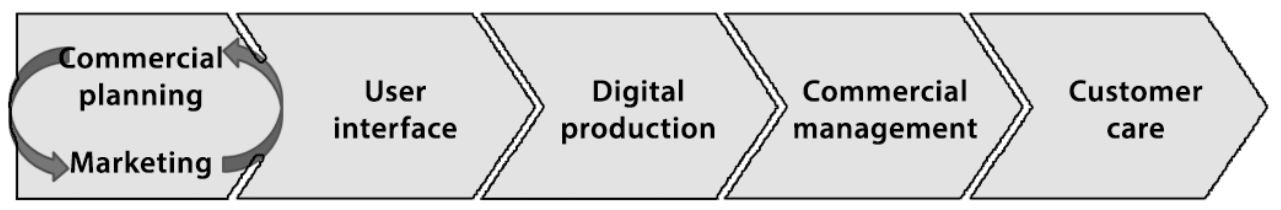

Technology 
This is a flexible business model closely anchored to the exploitation of synergies and economies of scale deriving from the integrated development of the two business lines.

The multi-brand line includes the activities of yoox.com and thecorner.com online stores.

Yoox.com, founded in 2000, is the virtual multi-brand fashion and design boutique that, thanks to its direct and consolidated relationship with designers, producers and authorized dealers, can offer a wide range of clothing, footwear and accessories of numerous international brands at reduced prices as they relate to the collection of the corresponding season of the previous year. A rich and particularly refined range of products, together with collections especially created for yoox.com that include vintage items, special editions of fashion designers, as well as books, art and design objects.

Thecorner.com, born in 2008, is the virtual space structured on the formula of the shop-in-shop, which means mini-shops with articles belonging to the current collections of famous, niche and craft brands, characterized by a relatively limited distribution and many of which hit the online channel for the first time. The prices of the products marketed through thecorner.com are in line with the prices applied in more traditional sales channels.

The mono-brand business line, on the other hand, includes the design, construction and exclusive management of the Online Stores of some of the leading fashion brands that wish to offer online the same collections also available in the physical stores.

Yoox's continuous growth has been constantly supported by continuous improvements in the Bologna automated techno-logistics platform, thanks to the considerable increase in product-handling and storage ability. The uniqueness of this project, which places Yoox at the forefront of its sector, lies in the combination of the use of the most modern automation systems and the use of RFID (Radio Frequency Identification) technology.

Technology is obviously fundamental to all these activities. Yoox joined the change induced by technology and managed to amplify its effects. The strategic use of technology has made it possible to manage e-commerce while at the same time cutting the high costs necessary to guarantee a luxury service: think of the high rental costs if you want to serve the same customers from the shops in the central streets of the major cities in the world.

Technology is also the binary on which the research activity in Yoox proceeds. The main topics are artificial intelligence and conversion to mobile. Regarding the first, a virtual personal shopper is under development, which could go to complete, if not even anticipate, those tips that even today personal shoppers provide to the demanding customers of luxury. 
At the same time, research devoted to improving and enhancing the mobile experience is more fundamental than ever. Today half of the purchases on Yoox online stores are already done through smartphones and tablets, and the percentage is destined to grow in the immediate future. This will allow Yoox to quickly move from the mobile-first company status to the next mobile-only degree.

\subsection{Investments and value created}

Innovating generally involves significant risks. An important investment is needed to develop an idea, make it concrete, launch it on the market and follow the trend. Yoox's investment used the following economic resources:

Table7: Group investments between 2009 and 2015 in thousands of euro

\begin{tabular}{|l|c|c|c|c|c|c|c|}
\hline & $\mathbf{2 0 0 9}$ & $\mathbf{2 0 1 0}$ & $\mathbf{2 0 1 1}$ & $\mathbf{2 0 1 2}$ & $\mathbf{2 0 1 3}$ & $\mathbf{2 0 1 4}$ & $\mathbf{2 0 1 5}$ \\
\hline intangibles & 2.184 & 6.065 & 9.114 & 14.582 & 18.386 & 23.988 & 53.897 \\
\hline tangibles & 1.170 & 6.275 & 14.515 & 15.679 & 14.227 & 10.944 & 29.850 \\
\hline Tot. & 3.354 & 12.340 & 23.629 & 30.261 & 32.613 & 34.932 & 83.748 \\
\hline
\end{tabular}

Investments in intangible assets mainly refer to multi-year development projects: these are costs incurred by Yoox for the development of specific projects with the aim of continuously developing innovative solutions for the creation and management of online stores. The remaining part of intangible investments is mainly attributable to expenses for the purchase and implementation of software for administrative and management uses. The expenses for the research activity, undertaken with the prospect of obtaining new knowledge and discoveries, scientific or technical, are recorded in the income statement when they are incurred.

Investments in tangible fixed assets are mainly linked to investments in the highly automated techno-logistics platform and to technological infrastructural investments, to the renewal or completion of furnishings for offices, to investment in new photographic studios as well as new automatic machines for photography. There is a sustained weight of investments financed through the stipulation of financial leasing contracts.

Yoox also continued to invest in innovation and consolidation of multichannel technology, with the aim of anticipating the trends of a rapidly expanding channel like the mobile one. The company believed and invested in the mobile channel since 2006, thus becoming a leader in mobile commerce ${ }^{36}$.

\footnotetext{
${ }^{36}$ Already in 2006, a year prior to the launch of the iPhone, Federico Marchetti created a task force within the YOOX technology team to grasp the enormous potential of the mobile commerce world. In 2016, mobile sales amounted to almost 50\% of the Group's revenue.
} 
The budget breakdown clarifies how these investments were funded and the results they have produced over time.

Taking the 2010-2014 period as a reference, the following are the main economic data of the company, useful for understanding the evolution of the main income and balance sheet items.

Table8: 2010-2014 Yoox's economic data

\begin{tabular}{|l|c|c|c|c|c|}
\hline & 2010 & 2011 & 2012 & 2013 & 2014 \\
\hline $\begin{array}{l}\text { Net Sales Rev- } \\
\text { enues }\end{array}$ & 214,3 & 291,2 & 375,9 & 455,6 & 524,3 \\
\hline EBITDA & 18,8 & 24,1 & 32,1 & 43,1 & 48,8 \\
\hline $\begin{array}{l}\text { Operating } \\
\text { Income }\end{array}$ & 15,0 & 16,4 & 18,9 & 23,9 & 23,3 \\
\hline Net Result & 9,1 & 10,0 & 10,2 & 12,6 & 13,8 \\
\hline
\end{tabular}

Table9: 2010-2014 Yoox's balance sheet figures

\begin{tabular}{|l|c|c|c|c|c|}
\hline $\begin{array}{l}\text { Net Working } \\
\text { Capital }\end{array}$ & 2010 & 2011 & 2012 & 2013 & 2014 \\
\hline $\begin{array}{l}\text { Net Invested } \\
\text { Capital }\end{array}$ & 45,9 & 69,6 & 87,2 & 99,2 & 127,3 \\
\hline $\begin{array}{l}\text { Net Financial } \\
\text { Position }\end{array}$ & $(22,8)$ & $(12,9)$ & $(14,6)$ & $(20,5)$ & $(31,0)$ \\
\hline Net Assets & 68,7 & 82,6 & 101,8 & 119,7 & 158,3 \\
\hline
\end{tabular}

Yoox made the results obtained for the benefit of a series of subjects directly or indirectly involved in operational activity sustainable over time.

The following quantitative parameters measure the wealth created by Yoox as of 31.12.2009, after 10 years of life and at the time of listing, and its distribution to the various categories of stakeholders. 
The Relationship Between Innovation \& Success: The Case Study of Yoox S.p.a. 135

Table 10: Economic value generated and distributed in the first ten years ${ }^{37} 38$

\begin{tabular}{|l|c|c|c|}
\hline & 31.12 .2009 & 31.12 .2008 & variance \% \\
\hline Economic value generated & 154.502 & 103.517 & $49,3 \%$ \\
\hline Net Sales Revenues & 152.217 & 101.450 & $50,0 \%$ \\
\hline Other income & 2.584 & 2.033 & $27,1 \%$ \\
\hline Financial income & 191 & 181 & $5,5 \%$ \\
\hline Devaluation of credits & $(63)$ & $(226)$ & $-72,1 \%$ \\
\hline Exchanges differences & $(427)$ & 79 & $>100 \%$ \\
\hline Distributed economic value & 147.594 & 98.952 & $49,2 \%$ \\
\hline Operating costs & 128.065 & 85.286 & $50,2 \%$ \\
\hline Remuneration of collaborators & 14.826 & 10.885 & $36,2 \%$ \\
\hline Remuneration of lenders & 1.131 & 1.407 & $-19,6 \%$ \\
\hline $\begin{array}{l}\text { Remuneration of the Public } \\
\text { Administration }\end{array}$ & 3.566 & 1.364 & $>100 \%$ \\
\hline Liberality & 6 & 11 & $-45,5 \%$ \\
\hline Economic value withheld & 6.908 & 4.566 & $51,3 \%$ \\
\hline Depreciation & 2.183 & 1.803 & $21,1 \%$ \\
\hline Provisions & 627 & 361 & $73,7 \%$ \\
\hline Reserves & 4.098 & 2.402 & $70,6 \%$ \\
\hline
\end{tabular}

\section{Conclusion}

The true strength of the Italian economy lies in market niches where companies can maintain their uniqueness and escape the replicating fury of competition. In a world of "replicants", where it is possible to replicate everything, uniqueness, attainable thanks to constant innovation, is the ability to escape the logic of homologation, preserving the originality of the business idea (D'Amato, Minella, Rebora, 2009). In the case study proposed were taken into consideration those variables (uniqueness of the product and of the positioning in the market, organizational model, technological innovation) that together generate the effect of a unique, competitive and successful company.

Yoox has well understood that:

- could not afford to compete with the big names in luxury clothing;

- At the same time, the use of the Internet and e-commerce in the luxury clothing market was growing.

The present study highlighted the trends of the online market in the period 2010-2015 that Yoox was able to interpret. Thanks to an excellent strategic anal-

Thousands of Euros (data source IAS/IFRS).

38 Includes deferred taxes. 
ysis of the competitive environment, Yoox has undergone radical innovation ${ }^{39}$, changing the competitive structures and dynamics of the target sector and creating a previously non-existent business environment. Leaning on the potential of the web and on its synergies with the luxury industry, Marchetti's company has succeeded in proposing an alternative sales channel, preferring to change the way in which products are made available to customers over acting directly on them.

Innovation, the basis of Yoox's success, has been conceived as a continuous and endless process, never experienced as a single successful episode. As mentioned above, innovation can lead the company onto unstable evolutionary paths that are difficult to predict, a condition that according to some authors ${ }^{40}$ may well represent an opportunity for learning rather than a threat: the innovations made by Yoox, which took a long period of time to develop, involved significant risks that the company was able to manage. In this regard, the present work carried out a quantitative analysis, through the balance sheet data, of the investments made to support the innovative effort and the results obtained over time, above all in terms of distributed value. At the strategic level, the study showed that in the very first phase of the project, characterized by the skepticism of the traditional market players and the partial distrust of consumers, top management adopted an innovative but not aggressive strategy, working mainly with out-of-series/season branded products and on creating strategic alliances with suppliers. At the same time, the company worked to differentiate itself from the traditional outlets/discounters, communicating excellently the philosophy pursued, ie that true fashion, even that of past seasons, has no time limit. With the growing trust of the market and consumers and with the consolidation of the brilliant results obtained, Yoox has gone as far as to establish itself as a real brand, distinct from the brands it proposed, preserving its natural vocation for innovation over time.

$39 \quad$ Henderson and Clark (1990) distinguish four different types of innovation: radical innovation consists of a completely new idea for the company and the context of reference that determines a clear discontinuity in respect to the past; incremental innovation represents the improvement of an existing product/process; architectural innovation redefines how to link the various components or phases of a product/process; finally, modular innovation is where the main components of the system are changed (eg changes in technology).

Henderson, R. M., Clark, K. B. (1990): Architectural Innovation: the Reconfiguration of Existing System and the Failure of Established Firms, Administrative Science Quarterly, n. 35, 9-30.

40 Kaplan, R. S., Norton, D. P. (2004): Strategy Maps: Converting Intangible Assets into Tangible Outcomes, Harvard Business School Press, Harvard. 


\section{Literature}

- Ansoff, H. I. (1957): Strategy for Diversification, Harward Business Review, vol. 35 , n. 5

- Bartlett, C. A., Ghoshal, S. (1992): What is a global manager?, Harward Business Review, vol. 70

- Bertelé, U., Mariotti, S. (1991): Impresa e competizione dinamica. Complessità economica, efficienza d'impresa e cambiamento industriale, Etas, Milano

- Birkinshaw, J. (1997): Entrepreneurship in Multinational Corporations: The Characteristics of Subsidiary Initiatives, Strategic Management Journal, vol. 18

- Bursi, T. (2007): I processi di internazionalizzazione delle piccole e medie imprese della provincia di Modena. Il ruolo degli investimenti diretti all'estero, FrancoAngeli, Milano

- Casson, M. (2005): Entrepreneurship and the theory of the firm, Journal of Economic Behavior \& Organization

- Ciappei, C., Poggi, A. (1997): Apprendimento e agire strategico d'impresa. Il governo delle dinamiche conoscitive nella complessità aziendale, Cedam, Padova

- Consolini, M., Di Saverio M., Loasses C. \& Richini P. (2013): Indicazioni per la programmazione e la realizzazione di iniziative per l'educazione all'imprenditorialità, ISFOL, Roma

- D’Amato, V., Minelli, E., Rebora, G. (2009): Alla ricerca dell'unicità. Il management imprenditoriale tra strategia, organizzazione e leadership, Franco Angeli, Milano

- Denicolai, S. (2009): Economia e management dell'innovazione. Governo e intermediazione della conoscenza come leva di competitività, Franco Angeli, Milano

- Dioguardi, G. (2000): L’impresa flessibile: una risposta alla competizione globale, in Bertelè U., Mariotti S., Impresa e competizione dinamica. Complessità economica, efficienza d'impresa e cambiamento industriale, Etas, Milano

- Drucker, P.F. (2002): The discipline of innovation, Harvard Business Review, vol. 80 , n. 8

- Freeman, C. (1982): The Economics of Industrial Innovation, MIT Press, Boston

- Henderson, R. M., Clark, K. B. (1990): Architectural Innovation: the Reconfiguration of Existing System and the Failure of Established Firms, Administrative Science Quarterly, n. 35

- Henry, J., Walker, D. (1991): Managing Innovation, Sage, London

- Kaplan, R. S., Norton, D. P. (2004): Strategy Maps: Converting Intangible Assets into Tangible Outcomes, Harvard Business School Press, Harvard

- Kirzner, I. (1973): Competition and Entrepreneurship, London University of Chicago Press, Chicago 
- Peters, T. (1982): Waterman R., In Search of Excellence, Harper \& Row, New York

- Porter, M. (1990): Competitive Advantage of Nations, Harvard Business Review, vol. 68, n. 2

- Preti, P., Puricelli, M. (2007): L'impresa forte. Un manifesto per le piccole imprese, Egea, Milano

- Rogers, M. (1998): The definition and measurement of innovation, Melbourne Institute of Applied Economics and Social Research, University of Melbourne, Melbourne Institute Working Paper

- Schumpeter, J. (1934): Theorie der Virtschaftlichen Entwicklung, Duncken \& Humboldt, Berlino

- Schumpeter, J. (1971): Teoria dello sviluppo economico, Sansoni Editore

- Simon, H., Zatta, D. (2007): Campioni nascosti. Come le piccole e medie imprese hanno conquistato il mondo, Il Sole 24 Ore, Milano

- Stampacchia, P., Bifulco, F. (2005): La gestione dei percorsi di innovazione, Giappichelli, Torino

- Thompson, A. V. (1965): Bureaucracy and innovation, Administrative Science Quarterly, vol. 10, n. 1

- Viale, R., Etzkowitz, H. (2008): The Capitalization of Knowledge: A Triple Helix of University-Industry-Government, Edward Elgar, Cheltenham, UK

- Vicari, S. (1998): La creatività dell'impresa. Tra caso e necessità, Etas, Milano

- Zaheer, S. (1995): Overcoming the Liability of Foreignness, Academy of management Journal, n. 38

- Zucchella, A., Onetti, A. (2008): Imprenditorialità, internazionalizzazione e innovazione: $i$ business model delle imprese biotech, Carocci, Roma

- Zucchella, A., Scabini, P. (2007): International Entrepreneurship, Palgrave, London 
Originalni naučni rad

Primljen 30.12.2017.

Odobren 14.03.2018.

\section{ODNOS IZMEĐU INOVACIJA I USPEHA: STUDIJA SLUČAJA KOMPANIJE YOOX S.P.A.}

U trenutnim konkurentnim uslovima, eksponencijalne stope rasta napretka $i$ tehnologije vode ka brzom trošenju ideja i proizvoda, što dovodi do smanjenja relativnog životnog veka proizvoda i marži. U ovom kontekstu, suštinske karakteristike proizvoda nisu više dovoljne, a sposobnost interpretiranja i unapređivanja stvarnih potreba tržišta postaju najvažnije. Osnovni cilj ovog rada je da naglasi stratešku važnost inovacija kao glavnog instrumenta koji kompanija može koristiti da bi se prilagodila promenama ili da bi postala njihov generator.

Studija slučaja koju predstavljamo istražuje razvojni put kompanije Yoox S.p.a., iz Italije, kompanije koja je orijentisana na inovacije. Analiza, koja se oslanja na snažne teoretske osnove, prati putanju rasta kompanije, I naglašava njenu izvanrednu sklonost ka inovacijama kao najvažnijeg faktora uspeha.

Dok smo analizirali ovu studiju slučaja, takođe smo naglasili ulogu koju kompanije imaju u stvaranju diskontinuiteta koji prekida i redefiniše ekvilibrijum kompetitivnog konteksta. Imajući u vidu ovaj aspekt, opisali smo model prvobitnog strateškog pozicioniranja i poslovni model koji su omogućili kompaniji Yoox da ponovo definiše tradicionalne tržišne granice i da redizajnira process kupovine.

Ključne reči: strategija, inovacije, tehnologija, razvoj 